\title{
IMMUNOMODULATORY EFFECTS OF ETHANOL EXTRACT OF ARTEMISIA VULGARIS L. IN MALE RATS
}

\author{
ROMA MARBUN, EDY SUWARSO, YUANDANI*
}

Department of Pharmacology, Faculty of Pharmacy, Universitas Sumatera Utara, Medan, Indonesia. Email: yuandani@usu.ac.id Received: 07 March 2018, Revised and Accepted: 25 March 2018

\begin{abstract}
Objective: This current study was conducted to investigate the immunomodulatory effects of ethanol extract of Artemisia vulgaris in male rats.

Methods: Immunomodulatory activity was determined by measuring the carbon elimination rate, the total number of leukocytes and differential, as well as antibody titer. The treatment groups were divided into six groups, each group consisting of five male rats. The extract at doses of $50,100,200$, and $400 \mathrm{mg} / \mathrm{kg}$ bw was administered orally for 7 days. The carbon elimination was measured using an ultraviolet-visible spectrophotometer.

Results: The ethanol extract of A. vulgaris at doses of 50,100, 200, and $400 \mathrm{mg} / \mathrm{kg}$ body weight increased the carbon elimination and increased the number of total leukocytes and differential leukocytes, especially neutrophils and neutrophils rod segments as compared to the negative control
\end{abstract} group (CMC-Na 0.5\%) (p<0.05).

Conclusion: The ethanol extract of $A$. vulgaris possesses immunomodulatory effect.

Keywords: Immunomodulatory, Artemisia vulgaris, Carbon clearance, Leukocyte.

(C) 2018 The Authors. Published by Innovare Academic Sciences Pvt Ltd. This is an open access article under the CC BY license (http://creativecommons. org/licenses/by/4. 0/) DOI: http://dx.doi.org/10.22159/ajpcr.2018.v11s1.26619

\section{INTRODUCTION}

Environment around us have different kinds of pathogens such as bacteria, virus, fungus, protozoa, and parasites that can cause infections in humans. Infections that occur in normal individuals are generally short and rarely leave permanent damage. This is due to the human body has a system called the immune system to respond and protect the body against the elements pathogens that can cause disease [1].

This system serves to protect the body from foreign substances that enter the body so that the function is not impaired. The immune system is beneficial for the prevention of a disease due to infection can be obtained naturally [2]. However, the natural immune system alone is not sufficient. Thus, an artificial immune system is also required by our body. Artificial immunity may be given by means of immunization. Immune response will be modulated by administering immunomodulatory agents [3].

Disease mediated by the immune system is a significant problem, such as HIV and ebola viruses' infection that requires an aggressive and innovative approach to the development of new treatments [4], thus should be given booster or immune enhancers. Among the many herbs used, one of them is Artemisia vulgaris $\mathrm{L}$. which is a plant of family Compositae.

Based on previous study, Binara plant (A. vulgaris L.) contains essential oils, saponins, flavonoids, and polyphenols. Previous studies also suggested $A$. vulgaris L. containing constituents such as tannins, polyphenols, flavonoids, saponins, minerals, and essential oil. Some of Artemisia spp. have been reported to have antimalarial activity, cytotoxic, antihepatotoxic, antibacterial, antifungal, and antioxidant activities [5].

Previous studies reported that Artemisia tripartite leaves have immunomodulatory activity [6]. Artemisia argyi is also widely used as antitumor and has immunomodulatory activity. Temraz and Walid suggest that $A$. vulgaris $\mathrm{L}$. has antioxidant activity. James et al. reported that utilization of species Artemisia has also been widely used in the world [7]. Investigation of the effect on immune system can be performed by various methods such as hemagglutination titer antibodies, delayed-type hypersensitivity response, and phagocytic activity test using carbon clearance method [8].

Phagocytic activity evaluation by using carbon clearance method is an established method to determine the non-specific immune system. Clearance carbon method is used to measure the activity of phagocytic cells to kill pathogens that enter the body and count the number of leukocyte cells. The hemagglutination titers of antibodies are a valuation of the specific immune system by measuring visual hemagglutination [8]. This current study was conducted to evaluate the effect of $A$. vulgaris extract on phagocytosis activity, total leukocytes and differential leukocytes, as well as antibody titer.

\section{MATERIALS AND METHODS}

\section{Materials}

The chemicals used in this study were ethanol (SmartLab, Indonesia) and natrium carboxymethyl cellulose (Na CMC) (Sigma, USA), imboost ${ }^{\circledR}$ (Soho, Indonesia), China ink (pelican B-17), acetic acid (SmartLab, Indonesia), and $\mathrm{NaCl}$ (Otsuka, Indonesia). Standard reagents for phytochemical screening were also used. A spectrophotometer (Shimadzu, Japan) was also used in this study.

\section{Plant materials}

The plants of A. vulgaris were collected from Medan, Sumatera Utara, Indonesia. Then, the plant was authenticated in Research Centre for Biology, Bogor, Indonesia.

\section{Phytochemical screening}

Phytochemical screening was performed to evaluate the presence of compounds such as alkaloids, flavonoids, glycosides, anthraquinone glycosides, saponins, tannins,and steroids/triterpenoids.

\section{Extraction procedure}

The plant materials were allowed to dry under shade. An amount of $1 \mathrm{~kg}$ of dried material of plant sample was ground and macerated in ethanol. The extraction was repeated twice on the residue. The filtrates were combined and the solvent was removed under reduced pressure to obtain extract of $A$. vulgaris. 


\section{Phagocytosis assay}

The phagocytosis ability was evaluated by carbon clearance method [9]. The extract at doses of 50,100, 200, and $400 \mathrm{mg} / \mathrm{kg}$ bw was administered orally for 7 days. On day 8 , blood sample was collected as a blank (minute 0 ), then $0.1 \mathrm{ml} / 10 \mathrm{~g}$ bw carbon ink suspension was injected intravenously through a vein in the tail, then $25 \mu \mathrm{l}$ blood samples were collected at min 5, 10, 15, and 20 after the injection of carbon. Then, $4 \mathrm{~mL}$ of $1 \%$ acetic acid was added to lyse the red blood cell. The measurement of absorbance was detected at a wavelength of $640.5 \mathrm{~nm}$ using an ultraviolet (UV)-visible spectrophotometer. After 12 $\mathrm{h}$ of blood collection, the rats were sacrificed; the liver and spleen of mice were taken and weighed [10].

Measurements of total leukocytes and differential leukocyte Figure 2 shows that $A$. vulgaris extract increased the number of total leukocytes and differential leukocytes, especially neutrophils and neutrophils rod segments as compared to the negative control group (CMC-Na 0.5\%) (P < 0.05). Examination of blood leukocyte cell count and differential leukocyte cell used blood on phagocytosis procedures. On day $8,1 \mathrm{ml}$ of blood was drawn and inserted into the tube which already contained Na-citrate to examine the number of total leukocyte and differential leukocyte cells.

\section{Data analysis}

Data were analyzed with SPSS using one-way ANOVA to determine an average difference among treatments. If there are differences, followed by Tukey post-hoc test was used to determine which variables that have differences. Based on the significant, value of $p<0.05$ was considered statistically significant.

\section{RESULTS}

Phytochemical screening of $A$. vulgaris is shown in Table 1.

Simplicia and extract contained chemical compounds, which include alkaloids, flavonoids, tannins, saponins, and glycosides [11]. According to Ghosh et al. that $A$. vulgaris L. contains flavonoids potential as an immunostimulant [12].

Constant elimination of carbon is one of the parameters used to determine the rate of phagocytosis. The greater the carbon elimination constant value, the higher the carbon clearance rate, which means faster phagocytic cells perform phagocytosis [10].

\section{Phagocytosis index}

The extract of $A$. vulgaris increased phagocytosis activity in a dosedependent manner. Increasing phagocytic index showed an increase in phagocytic activity of macrophages and an increase in non-specific immunity. Macrophages are responsible for conducting the process of elimination, especially in the liver and the rest are in the spleen [10]

\section{Stimulation index}

Table 3 shows the stimulation index value of ethanol extract of A. vulgaris on phagocytic activity. Stimulation index is a comparison between the test group and control group. Previous research declared a substance is an immunostimulatory agent if the stimulation index $<1$ and is immunosuppressive if the stimulation index is smaller than 1 [13].

\section{DISCUSSION}

Carbon elimination rate is a method used to measure the phagocytic activity in mice. Carbon will diminish in number in the blood along with the increase of time, because of the events of phagocytosis by cells of leukocytes, especially neutrophils, monocytes, macrophages, and eosinophils [13]. Carbon elimination rate was measured at minute 5, 10,15 , and 20 . The elimination rate of carbon was measured by UVvisible spectrophotometer at a wavelength of $640.5 \mathrm{~nm}$. The average value of the constant elimination of carbon can be seen in Table 2 .
Table 1: Results of phytochemical screening of A. vulgaris

\begin{tabular}{llll}
\hline No & Screening of & Dried powdered & Extracts \\
\hline 1 & Alkaloids & + & + \\
2 & Flavonoids & + & + \\
3 & Tannin & + & + \\
4 & Saponin & + & + \\
5 & Glycosides & + & + \\
6 & Steroids/triterpenoids & - & - \\
\hline
\end{tabular}

+: Contains classes of compounds, -: Not containing the compound.

A. vulgaris: Artemisia vulgaris

Table 2: Results of constant value carbon elimination ( \pm SEM)

\begin{tabular}{|c|c|c|}
\hline No. & Group treatment & $\begin{array}{l}\text { Carbon elimination } \\
\text { constant }(\text { mean } \pm S E M)\end{array}$ \\
\hline 1 & CMC Na $0.5 \%$ & $0.0645 \pm 0.0013(+)$ \\
\hline 2 & Imboost $32.5 \mathrm{mg} / \mathrm{kg}$ & $0.0041 \pm 0.0002(*,+)$ \\
\hline 3 & A. vulgaris extract $50 \mathrm{mg} / \mathrm{kg}$ bw & $0.0183 \pm 0.0039(*,+)$ \\
\hline 4 & A. vulgaris extract $100 \mathrm{mg} / \mathrm{kg}$ bw & $0.0154 \pm 0.0013(*,+)$ \\
\hline 5 & A. vulgaris extract $200 \mathrm{mg} / \mathrm{kg} \mathrm{bw}$ & $0.0110 \pm 0.0010(*,+)$ \\
\hline 6 & A. vulgaris extract $400 \mathrm{mg} / \mathrm{kg}$ bw & $0.0085 \pm 0.0004(*,+)$ \\
\hline
\end{tabular}

Table 3: Stimulation index values

\begin{tabular}{ll}
\hline Treatment group & Stimulation index \\
\hline CMC Na $0.5 \%$ & 1.11 \\
Imboost $32.5 \mathrm{mg} / \mathrm{kgBB}$ & 1.36 \\
A. vulgaris extract $50 \mathrm{mg} / \mathrm{kg} \mathrm{bw}$ & 1.11 \\
A. vulgaris extract $100 \mathrm{mg} / \mathrm{kg} \mathrm{bw}$ & 1.19 \\
A. vulgaris extract $200 \mathrm{mg} / \mathrm{kg} \mathrm{bw}$ & 1.27 \\
A. vulgaris extract $400 \mathrm{mg} / \mathrm{kg} \mathrm{bw}$ & 1.34 \\
\hline
\end{tabular}

A. vulgaris: Artemisia vulgaris

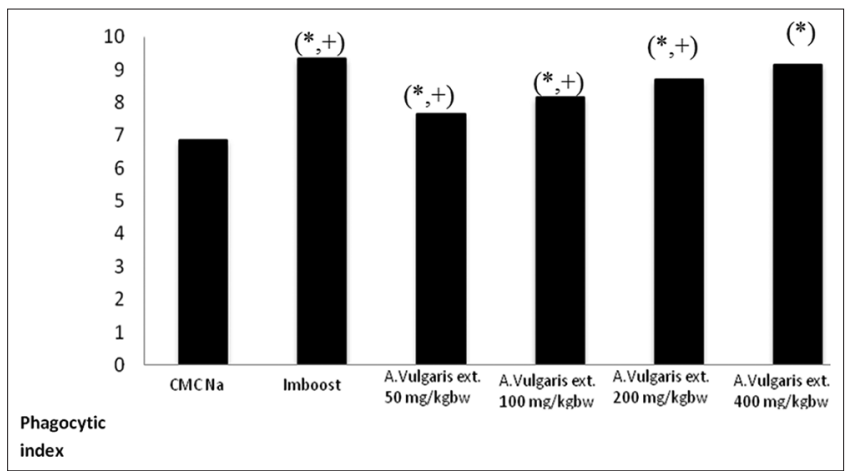

Figure 1: Phagocytic index in male rats (mean \pm standard error of the mean, $n=5)^{*} p<0.05$, significant to the CMC Na $0.5 \%$. $+p<0.05$, significant to the suspension Imboost ${ }^{\circledR}$

The ethanol extract of $A$. vulgaris increased the number of leukocytes, especially neutrophils. Neutrophils are the first leukocytes recruited to the site of infection. They play majo role in innate immune response [15].

Fig. 1 shows that the negative control group suspensions CMC Na $0.5 \%$ to 6.8529 phagocytosis index was significantly different $(\mathrm{p}<0.05)$ with the other treatment groups. The extract at $50 \mathrm{mg} / \mathrm{kg}$ bw has 7.637 phagocytosis index which was significantly different $(\mathrm{p}<0.05)$ with the other treatment groups. The extract at $100 \mathrm{mg} / \mathrm{kg}$ bw with an index of phagocytosis 8.1513 and $200 \mathrm{mg} / \mathrm{kg}$ with 8.6964 phagocytosis index did not have a statistically significant difference ( $p>0.05$ ) but differ significantly with $400 \mathrm{mg} / \mathrm{kg}$ with the phagocytic index of 9.1603 and Imboost $^{\circledR}$ with phagocytic index of 9.3186 . 


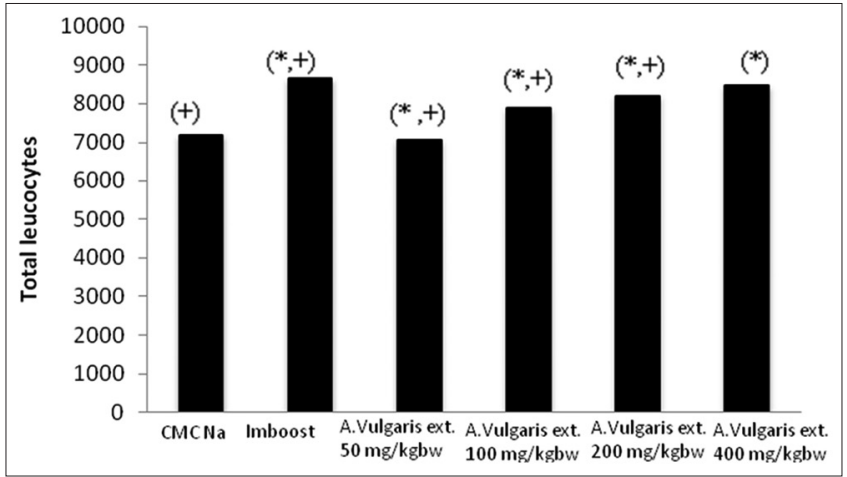

Figure 2: Result of measurement of white blood cell count of rats (mean \pm standard error of the mean). ${ }^{*} \mathbf{p}<0.05$, significant to the CMC Na $0.5 \%,+p<0.05$, significant to the Suspensi Imboost ${ }^{\circledR}$

The extract at $400 \mathrm{mg} / \mathrm{kg}$ and Imboost ${ }^{\circledR}$ did not has a statistically significant difference $(\mathrm{p}>0.05)$

The extract at 50,100, 200, and $400 \mathrm{mg} / \mathrm{kg}$ bw showed that their relationship with the dose increase stimulation index value, the greater the increase in the dose of stimulant-derived index value increases. It shows that $A$. vulgaris is a substance that is immunostimulatory agent.

Compounds that may act as an immunostimulant are flavonoids and alkaloids. This is consistent with previous study by Prastiwi et al., which states that the alkaloids, saponins, and tannins have immunostimulatory activity as that alleged immunostimulatory activity of $A$. vulgaris may be caused by the flavonoids and alkaloids in the ethanol extract is known by phytochemical screening [14].

\section{CONCLUSION}

The ethanol extract of $A$. vulgaris can increase the phagocytic activity of macrophage cells in male rats injected carbon suspension. The extract at doses of 50,100,200, and $400 \mathrm{mg} / \mathrm{kg}$ may affect phagocytic activity compared to the negative control $0.5 \%$ CMC-Na $(\mathrm{p}<0.05)$. The extract at $400 \mathrm{mg} / \mathrm{kg}$ gives phagocytic effect similar to the positive control Imboost ${ }^{\circledR}$. Extract ethanol of herb Binara (A. vulgaris $\mathrm{L}$.) increases the total number of cells of leukocytes and neutrophils part differential leukocyte cells and stem segments in male rats.

\section{REFERENCES}

1. Temraz A, Walid T. Characterization of antioxidant activity of extract from Artemisia vulgaris. Pak J Pharm Sci 2008;21:321-6.

2. Kresno BS. Imunologi: Diagnosis and laboratory process. Facult Med Publ 2001;5:10-2.

3. Yuandani, Jantan I, Ilangkovan M, Husain K, Chan KM. Inhibitory effects of compounds from Phyllanthus amarus on nitric oxide production, lymphocyte proliferation, and cytokine release from phagocytes. Drug Des Devel Ther 2016;10:1935-45.

4. Dash S, Nath LK, Bhise S, Kar PB. Stimulation of immune function activity by the alcoholic root extract of Heracleum nepalense D.Don. Indian J Pharmacol 2006;38:336-40.

5. Nawab A, Yunus M, Mahdi AA, Gupta S. Evaluation of anticancer properties of medicinal plants from the Indian sub-continent. Mol Cell Pharm J 2011;3:21-9.

6. Bao Y, Li Y, Jiang Q, Zhao L, Xue T, Hu B, et al. Methylthioadenosine/ S-adenosyl homocysteine nucleosidase (Pfs) of Staphylococcus aureus is essential for the virulence independent of LuxS/AI-2 system. Int J Med Microbiol 2013;303:190-200.

7. James D, Garcia C, Garg G. Mugwort (Artemisia vulgaris, Artemisia douglasiana, Artemisia argyi) in the treatment of menopause, premenstrual syndrome, dysmenorrhea and attention deficit hyperactivity disorder. Chin Med J 2012;25:116-23.

8. Shukla SP, Mianty K, Jiran KH. Establishing the reliability of palatal rugae pattern in individual identification (following orthodontic treatment). J Forensic Odontostomatol 2009;29:20-9.

9. Farnsworth NR. Biological and phytochemical screening of plants. J Pharm Sci 1966;55:263-4.

10. Aldi Y, Mahyudin, Handayani D. Activity test of some sub fraction of Herba Meniran ethyl acetate (Phyllanthus niruri Linn.) against active kutan hypersensitivity reactions. J Pharm Sci Tech 2013;18:9-16.

11. Harborne B. Phytochemical Methods. $3^{\text {rd }}$ ed. United of Kingdom: University of Reading; 2013. p. 214

12. Ghosh T, Mitra P, Mitra PK. Effect of leaves of Artemisia vulgaris L. on growth of rats. Int J Herbs Med 2013;1:30.

13. Faradilla M. Effects of immunomodulator polysaccharide rhizome white ginger (Curcuma zedoaria (Christm.) Roscoe). J Pharm Sci Indones 2014;12:25-7.

14. Prastiwi R, Tjahyadi, Chusun. Test effect of tonic ethanol extract herb Centella asiatica (Centella asiatica (L). Urb) In Balb/c. J Phytopharm 2015;5:23-5.

15. Kobayashi SD, Voyich JM, Burlak C, DeLeo FR. Neutrophils in the innate immune response. Arch Immunol Ther Exp (Warsz) 2005;53(6):505-17. 